\title{
Microbial fuel cell-based biosensor for toxic carbon monoxide monitoring
}

\author{
Zhou, Shaofeng; Huang, Shaobin; Li, Yi; Zhao, Nannan; Li, Han; Angelidaki, Irini; Zhang, Yifeng
}

Published in:

Talanta

Link to article, DOI:

10.1016/j.talanta.2018.04.084

Publication date:

2018

Document Version

Peer reviewed version

Link back to DTU Orbit

Citation (APA):

Zhou, S., Huang, S., Li, Y., Zhao, N., Li, H., Angelidaki, I., \& Zhang, Y. (2018). Microbial fuel cell-based biosensor for toxic carbon monoxide monitoring. Talanta, 186, 368-371.

https://doi.org/10.1016/j.talanta.2018.04.084

\section{General rights}

Copyright and moral rights for the publications made accessible in the public portal are retained by the authors and/or other copyright owners and it is a condition of accessing publications that users recognise and abide by the legal requirements associated with these rights.

- Users may download and print one copy of any publication from the public portal for the purpose of private study or research.

- You may not further distribute the material or use it for any profit-making activity or commercial gain

- You may freely distribute the URL identifying the publication in the public portal

If you believe that this document breaches copyright please contact us providing details, and we will remove access to the work immediately and investigate your claim. 


\section{Author's Accepted Manuscript}

Microbial fuel cell-based biosensor for toxic carbon monoxide monitoring

Shaofeng Zhou, Shaobin Huang, Yi Li, Nannan Zhao, Han Li, Irini Angelidaki, Yifeng Zhang

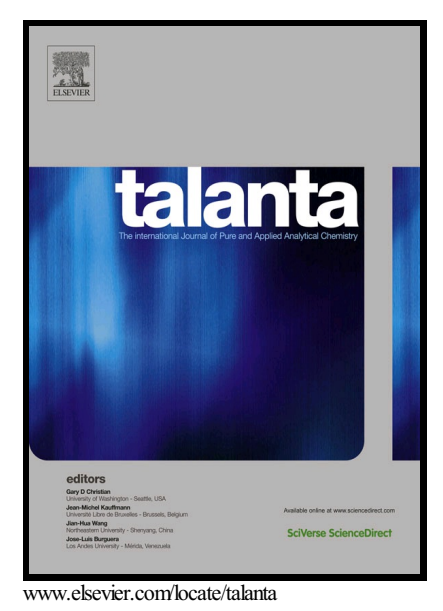

PII: $\quad$ S0039-9140(18)30440-5

DOI: $\quad$ https://doi.org/10.1016/j.talanta.2018.04.084

Reference: TAL18623

To appear in: Talanta

Received date: 30 January 2018

Revised date: 23 April 2018

Accepted date: 26 April 2018

Cite this article as: Shaofeng Zhou, Shaobin Huang, Yi Li, Nannan Zhao, Han Li, Irini Angelidaki and Yifeng Zhang, Microbial fuel cell-based biosensor for toxic carbon monoxide monitoring, Talanta, https://doi.org/10.1016/j.talanta.2018.04.084

This is a PDF file of an unedited manuscript that has been accepted for publication. As a service to our customers we are providing this early version of the manuscript. The manuscript will undergo copyediting, typesetting, and review of the resulting galley proof before it is published in its final citable form. Please note that during the production process errors may be discovered which could affect the content, and all legal disclaimers that apply to the journal pertain. 


\section{ACCEPTED MANUSCRIPT}

\section{Microbial fuel cell-based biosensor for toxic carbon monoxide monitoring}

Shaofeng Zhou ${ }^{\mathrm{a}, \mathrm{b}}$, Shaobin Huang ${ }^{\mathrm{a}}$, Yi $\mathrm{Li}^{\mathrm{a}}$, Nannan Zhao ${ }^{\mathrm{a}}$, Han $\mathrm{Li}^{\mathrm{a}}$, Irini Angelidaki ${ }^{\mathrm{b}}$, Yifeng Zhang $^{\text {b,* }}$

${ }^{a}$ School of Environment and Energy, South China University of Technology, Higher Education Mega Center, Guangzhou 510006, PR China

${ }^{b}$ Department of Environmental Engineering, Technical University of Denmark, DK-2800 Lyngby, Denmark

*Corresponding author: Department of Environmental Engineering, Technical University of Denmark, Denmark, Tel: (+45) 91989992; yifz@env.dtu.dk

\section{ABSTRACT}

This study presents an innovative microbial fuel cell-based biosensor for carbon monoxide (CO) monitoring. The hypothesis for the function of the biosensor is that $\mathrm{CO}$ inhibits bacterial activity in the anode and thereby reduces electricity production. A mature electrochemically active biofilm on the anode was exposed to $\mathrm{CO}$ gas at varied concentrations. A proportional linear relationship $\left(\mathrm{R}^{2}=\right.$ $0.987)$ between $\mathrm{CO}$ concentration and voltage drop $(0.8$ to $24 \mathrm{mV})$ in the range of $10 \%$ and $70 \%$ of CO concentration was observed. Notably, no further decrease of voltage output was observed by with further increasing $\mathrm{CO}$ concentration over $70 \%$. Besides, the response time of the biosensor was $1 \mathrm{~h}$. The compact design and simple operation of the biosensor makes it easy to be integrated in 
existing CO-based industrial facilities either as a forewarning sensor for $\mathrm{CO}$ toxicity or even as an individual on-line monitoring device.

\section{Graphical Abstract:}

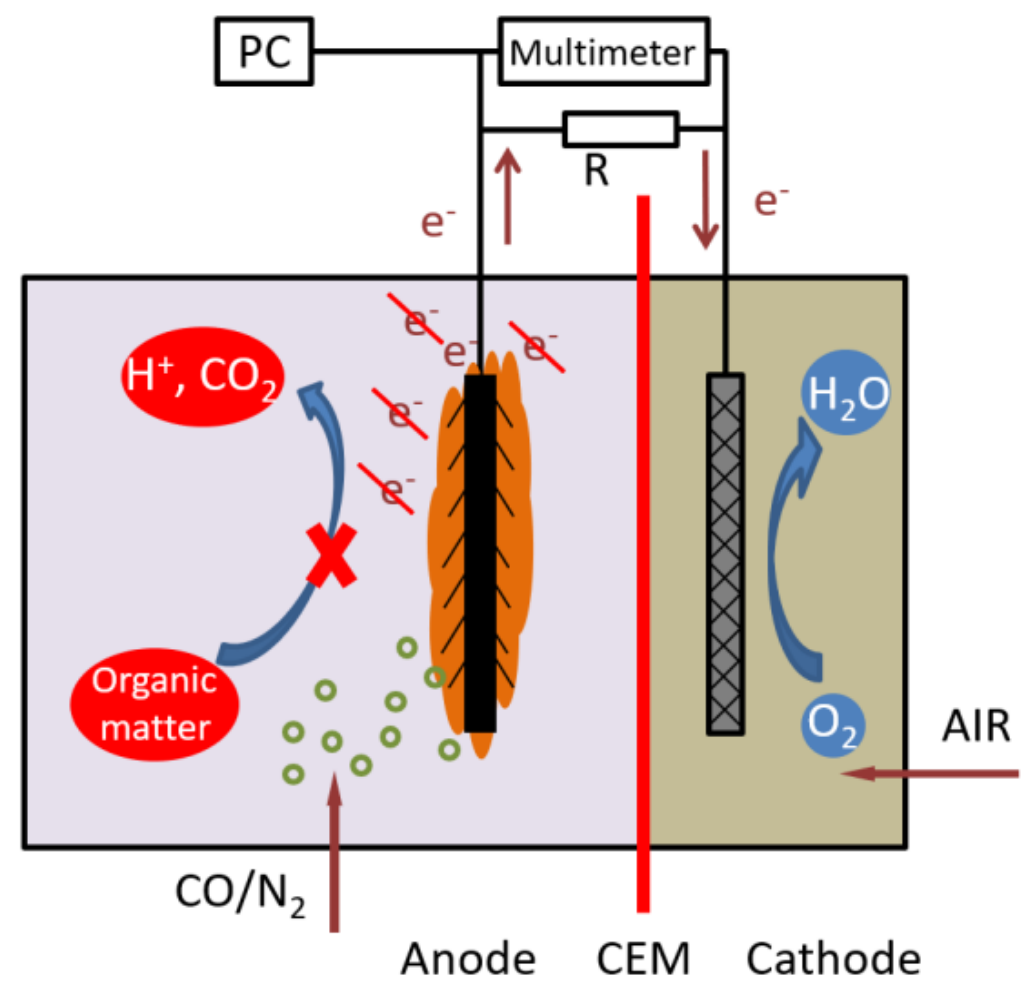

Table of Contents Art

Keywords: Microbial fuel cells; Carbon monoxide; Biosensor; Toxicity; Gas phase; Voltage 


\section{ACCEPTED MANUSCRIPT}

\section{Introduction}

Carbon monoxide (CO) is considered as one of the most hazardous gasses for human health. Moreover, $\mathrm{CO}$ imposes negative environmental impact Unfortunately, significant emissions of CO are generated as a byproduct of power plants and other human chemical activities (Diender et al., 2015; Paliwal et al., 2017). Thus, timely gas leakage detection or forewarning is important for protecting human beings and work places from $\mathrm{CO}$ inroad. Over the last decades, a great deal of research has been dedicated in development of optical, semiconductor or electrochemical $\mathrm{CO}$ sensors. These sensors present high sensitivity and could detect $\mathrm{CO}$ at very low concentrations ranging from 1 ppm to hundreds ppm (Kundu et al., 2018; Shojaee et al., 2018; Zhou et al., 2018). However, CO liberated from incomplete combustion or steel mill industry is usually at much higher levels (Im et al., 2017). So far, there is not any compact form of sensors focusing on the detection of high concentrations of $\mathrm{CO}$. Besides, most of conventional sensors need noble metal fabrications which make them relatively expensive. Moreover, many conventional CO sensors operate at high temperatures (above $100{ }^{\circ} \mathrm{C}$ ), and thus, are energy intensive. Thus, a simple, efficient and costeffective sensor capable of CO monitoring at high concentrations, is needed.

Recently, various microbial fuel cell (MFC)-based biosensors have been presented. MFC are attractive as biosensors due to the sustainability, and also the easily detected signal. MFC biosensors have been extensively studied for various monitoring applications such as microbial activity, chemical/biochemical oxygen demand (Zhang and Angelidaki, 2011), volatile fatty acids (Jin et al., 2016; Jin et al., 2017) , nitric oxide reduction (Zhou et al., 2016) and heavy metals (e.g. $\mathrm{Cu}^{2+}$ ) (Jiang et al., 2015; Shen et al., 2013). MFC-based biosensors have also been employed to detect toxicity of specific pollutants (e.g. formaldehyde, $\mathrm{Cu}^{2+}$ ) based on potential toxicity on exoelectrogens and reduction of electricity production (Sun et al., 2015). 


\section{ACCEPTED MANUSCRIPT}

Although CO could be utilized by Clostridium species as substrate (Hussain et al., 2011), it is toxic to most of microorganisms. Thus, $\mathrm{CO}$ could also inhibit activity of bioanode in MFC and the drop of voltage could be an indicator of CO concentration. In this study, an MFC with mature anode biofilm was developed for the first time, to monitor $\mathrm{CO}$ concentration (termed as bioelectrical $\mathrm{CO}$ sensor). The objectives of this proof-of-concept study were (i) to demonstrate the feasibility of MFC for monitoring at high $\mathrm{CO}$ concentrations, (ii) to elucidate the correlation between voltage and CO concentration.

\section{Materials and methods}

\subsection{Reactor configuration and startup}

The MFC reactor used in this study consisted of two rectangular chambers made of nonconductive polycarbonate plates. The volume of anodic and cathodic chamber was of 70 and $35 \mathrm{~mL}$, respectively. Two chambers were separated by a cation exchange membrane (CEM) (CMI 7000, Membrane international, NJ). The anode electrode was carbon brush $(5.9 \mathrm{~cm}$ in diameter, $6.9 \mathrm{~cm}$ in length, Mill-Rose, USA) which was thermally pretreated at $450{ }^{\circ} \mathrm{C}$ for $10 \mathrm{~min}$ prior to use. Exoelectrogenic biofilm were enriched in the anode by inoculating with domestic wastewater which was taken from primary clarifier (Lyngby Wastewater Treatment Plant, Copenhagen, Denmark) and amended with $1 \mathrm{~g} / \mathrm{L}$ sodium acetate $(\mathrm{NaAc})$. Cathode electrode was made of Titanium mesh $(4 \mathrm{~cm}$ $\times 3.5 \mathrm{~cm})$ coated with $\mathrm{Pt} / \mathrm{C}\left(0.5 \mathrm{mg}(\mathrm{Pt}) / \mathrm{cm}^{2}\right)$. The cathode chamber was filled by $50 \mathrm{mM}$ phosphate buffer (PBS, PH 7.0) and constantly aerated by a pump through a sterile needle connected with 45 $\mu \mathrm{m}$ filter. Electric circuit between anode and cathode electrodes was connected via a $1000 \Omega$ external resistance for voltage recording. After approximately 40 days operation, stable electrical energy output (620 $\pm 20 \mathrm{mV}$, set as baseline of sensing) was achieved in several successive batch assays, which indicated that electro-active biofilm was well established on the anode. 


\section{ACCEPTED MANUSCRIPT}

\section{$2.2 \mathrm{CO}$ sensing tests}

During batch tests, wastewater was replaced by nutrient solution $(\mathrm{pH} 7.2 \pm 0.5)$ containing $50 \mathrm{mM}$ PBS, $0.13 \mathrm{~g} / \mathrm{L} \mathrm{KCL}, 0.31 \mathrm{~g} / \mathrm{L} \mathrm{NH}_{4} \mathrm{Cl}, 1 \mathrm{~g} / \mathrm{L} \mathrm{NaAc}$, vitamin solution and trace mineral solution as previously described (Zhang and Angelidaki, 2015). This nutrient solution was added to the anode chamber prior to each test to maintain the same conductivity and $\mathrm{pH}$. Previously study indicated that effect of $\mathrm{CO}$ on conductivity and $\mathrm{pH}$ was negligible due to its poor solubility.

Before initiation of each batch test, the anode was flashed with nitrogen to remove oxygen. Subsequently, different concentrations of CO (from $0 \%$ to $100 \%$ at $10 \%$ interval, mixed with nitrogen) were fed into the anode through a peristaltic pump at $4 \mathrm{~mL} / \mathrm{min}$ (OLE DICH, Instrumentmakers Aps, Denmark) (Figure 1). A gas-diffuser was set on the bottom of anode chamber to cut $\mathrm{CO}$ into micro-bubbles upwards. After each test, the anolyte was refilled with forementioned fresh nutrient solution to acquire fully recovery of electricity production. All the tests were conducted in replicate in water bath at $25 \pm 0.5^{\circ} \mathrm{C}$.

\subsection{Chemicals and analyses}

All chemicals were analytical pure without further purification. $\mathrm{CO}$ was purchased from AGA Industrial Gases (Denmark). Voltage across the resistance was recorded at 5 min intervals throughout the test using a potentiostat (CT-4008W, Neware Battery Testing System, China).

\section{Results and discussion}

The bioelectrical $\mathrm{CO}$ sensor was tested with different $\mathrm{CO}$ concentrations (as percentage). Figure 2 illustrates the correlation of voltage drop which was determined as the voltage difference before and 1 hour after adding $\mathrm{CO}$ in the anode. It can be seen that voltage drop was increased with the 


\section{ACCEPTED MANUSCRIPT}

increasing of $\mathrm{CO}$ concentrations. Detectable inhibition ( 1 mV drop) firstly appeared when $10 \%$ $\mathrm{CO}$ (mixed with $90 \%$ of $\mathrm{N}_{2}$ ) was pumped into the anode chamber. Approximately $24 \mathrm{mV}$ of voltage drop was observed when CO concentration was up to $70 \%$ and then leveled out in the range of $22 \sim$ $34 \mathrm{mV}$ for higher $\mathrm{CO}$ concentrations. Overall, the regression coefficient $\left(\mathrm{R}^{2}{ }_{\text {adj }}\right)$ was 0.987 which indicated that the biosensor could be used to monitor the $\mathrm{CO}$ concentrations in the range of $10 \%$ to 70\%. As anolyte was amended with sufficient sodium acetate which provided sufficient substrate for continuous electricity generation, the voltage decrease could only be explained by the slight inhibition effect of $\mathrm{CO}$ on the exoelectrogens, and thereby reducing the amounts of electrons generated from microbial metabolism. When the $\mathrm{CO}$ concentration was below $10 \%$, toxicity was hardly detected. However, when $\mathrm{CO}$ was higher than $70 \%$, the voltage did not decrease further probably due to the limited solubility of $\mathrm{CO}$ in the anolyte. These results indicate that MFC can be an effective biosensor for $\mathrm{CO}$ monitoring. $\mathrm{CO}$ could affect the current generation of MFC biosensor in two different ways. Firstly, similar to human CO poisoning, carbon monoxide might chelate with enzymes, which are involved in extracellular electron transfer or cell growth (Hussain et al., 2014). Secondly, CO may influence the metabolic processes.

The response time (RT), defined as the minimum time needed to acquire a reliable voltage measurement correlating to $\mathrm{CO}$ concentration was assessed. The biosensor became more sensitive (shorter RT) at higher $\mathrm{CO}$ concentrations (Figure 3a). Accordingly, circuit current needed more time to recover to the former level after $\mathrm{CO}$ exposure. To be more specific, no lag phase of recovery was needed when $\mathrm{CO}$ inlet concentration was lower than $10 \%$ while it would take more than an hour to fully recover when $70 \%$ to $100 \%$ CO was tested. Actually, the voltage output would not immediately stop decreasing after the exposure at high CO levels. Instead, the voltage continued decreasing for approximately $20 \mathrm{~min}$ after $\mathrm{CO}$ was replaced by nitrogen. It could be deduced that 


\section{ACCEPTED MANUSCRIPT}

the toxicity of $\mathrm{CO}$ might have negatively affected the microbial metabolism rather than thermodynamic electron-transfer reactions. Figure $3 b$ presents the different regression coefficients $\left(\mathrm{R}^{2}\right)$ between current and $\mathrm{CO}$ concentrations at different operating-time. Apparently, the correlation became more linear when the reaction time increased. The results indicated that in order to acquire an accurate monitoring of $\mathrm{CO}$ concentration, at least one-hour response time ( $\mathrm{R}^{2}$ of 0.987$)$ should be applied (Figure 3b).

Benefit from better characteristics of chemical catalysts, chemical based CO sensors (Table 1) generally presented higher selectivity and precision than other conventional sensors. However, chemical catalysts are mostly heavy metals and expensive and may cause environmental pollution upon use due to the utilization of potential toxic chemicals. Furthermore, most of other recently developed $\mathrm{CO}$ sensors require either high temperature or involve complex noble metals which make them uneconomical feasible. The bioelectrical $\mathrm{CO}$ sensor reported here is a simple and cheap alternative as no additional signal transducer and chemicals were needed. The electricity consumption of operation was calculated as only $0.2 \mathrm{KW} \cdot \mathrm{h}$, which was mainly consumed by air pump. It is the first time that bioelectrochemical system has been proposed for CO sensing. The bioelectrical $\mathrm{CO}$ sensor developed in this study is suitable on relatively higher concentrations of $\mathrm{CO}$ than other sensors. Therefore the bioelectrical CO sensor may fulfil its potency in respect to various industrial processes related to high emissions of carbon monoxide (Devarapalli et al., 2016).

It has been reported that some acetogenic bacteria like Clostridia sp. could use CO as substrate in MFC for electricity production (Devarapalli et al., 2016; Hussain et al., 2014). However, electricity generated from CO was not observed in this study, which could be due to the different anodic conditions (e.g., inocula). It could be evidenced that even with $100 \% \mathrm{CO}$, voltage was stabilizing at background value $(\sim 20 \mathrm{mV})$ during operation time after fully depletion of acetate 
(Figure 4). Besides, in this study, the voltage drop started to decline at $10 \% \mathrm{CO}$ even with adequate acetate addition (Figure 2), which indicated that the pre-acclimated mature electro-activated biofilm was adapted to acetate rather than carbon monoxide. It has been reported that $\mathrm{CO}$ flux higher than $1.02 \mathrm{~L} / \mathrm{d}$ (corresponding to $25 \%$ in this study) severely inhibited anodic activity (Mehta et al., 2010). To date, the most common intermediate/product for $\mathrm{CO}$ fermentation was acetic acid (Abubackar et al., 2016), while a large amount of which was added in anode chamber as electron donors. CO fermentation was consequently hindered due to the thermodynamics balance. It could also be evidenced that no ethanol was detected in the system (data not shown).

\section{Implications}

The bioelectrical sensor developed here shows promising perspectives. For instance, it can find applications in areas where high CO emissions can arise such as incineration facilities. Furthermore, the sensor has economic merits as it operates at room temperature, does not need expensive noble metals as sensing elements and can operate without electricity input if a single-chamber MFC with air cathode is employed.

Though promising, the bioelectrical sensor still has some challenges in terms of operation, sensitivity and selectivity. Toxic gases are unlikely emerged as pure $\mathrm{CO}$, thus further research is in progress to focus on the selectivity and stability, identifying the potential affecting factors and underlying sensing mechanisms with respect to microbiology. Last but not least, as microbes in anode are easily transformed, which means they are vulnerable if being exposed for the long-term in toxic conditions, the microbial flora should be examined. Thus the system need to be further optimized for ensuring correct monitoring in field application.

\section{Conclusion}




\section{ACCEPTED MANUSCRIPT}

This study for the first time investigated the feasibility of MFC-typed sensor for CO detection, employing anode exoelectrogens as key element. Reproducible voltage drops caused by CO toxicity as indicating signals were obtained to designate $\mathrm{CO}$ concentrations. A linear relationship $\left(\mathrm{R}^{2}=\right.$ 0.987) between the electric signals and CO concentrations was discovered over the range of $10 \%$ to $70 \%$ and 50 min to one-hour response time was recommended. This novel biosensor could be in situ employed in remote places where electricity is in absence as the monitoring system operates without electricity addition. Though the bioelectrical $\mathrm{CO}$ sensor has a potential, further improvements of anti-interference and selectivity, as well as reactor optimization for more compact configuration, is of significance to fit applicable demands.

\section{Acknowledgement}

The authors would like to thank Hector Garcia and Hao Sun for technical assistance. This study is financially supported by the Oversea Study Program of Guangzhou Elite Project (GEP), the National Natural Science Foundation of China (Grants No. U1701243 and 51708184), Research

Project of Guangdong Provincial Department of Science and Technology (Grants No. 2016B020240002 and 2015B020236001), and The Danish Council for Independent Research (DFF1335-00142).

\section{Conflict of interest statement}

The authors declare that there is no conflict of interest. 


\section{ACCEPTED MANUSCRIPT}

\section{Reference}

Abubackar HN, Bengelsdorf FR, Duerre P, Veiga MC, Kennes C. Improved operating strategy for continuous fermentation of carbon monoxide to fuel-ethanol by clostridia. Applied Energy 2016; 169: 210-217.

Bergmann M, Egert M, Plenio H. Malodorogenic Sensing of Carbon Monoxide. Chemistry-a European Journal 2017; 23: 13328-13331.

Devarapalli M, Atiyeh HK, Phillips JR, Lewis RS, Huhnke RL. Ethanol production during semicontinuous syngas fermentation in a trickle bed reactor using Clostridium ragsdalei. Bioresour Technol 2016; 209: 56-65.

Diender M, Stams AJ, Sousa DZ. Pathways and Bioenergetics of Anaerobic Carbon Monoxide Fermentation. Front Microbiol 2015; 6: 1275.

Dong M, Zheng C, Miao S, Zhang Y, Du Q, Wang Y, et al. Development and Measurements of a Mid-Infrared Multi-Gas Sensor System for $\mathrm{CO}, \mathrm{CO}_{2}$ and $\mathrm{CH}_{4}$ Detection. Sensors (Basel, Switzerland) 2017; 17.

Hussain A, Bruant G, Mehta P, Raghavan V, Tartakovsky B, Guiot SR. Population Analysis of Mesophilic Microbial Fuel Cells Fed with Carbon Monoxide. Applied Biochemistry and Biotechnology 2014; 172: 713-726.

Hussain A, Guiot SR, Mehta P, Raghavan V, Tartakovsky B. Electricity generation from carbon monoxide and syngas in a microbial fuel cell. Applied Microbiology and Biotechnology 2011; 90: 827-836.

Im CH, Kim C, Song YE, Oh S-E, Jeon B-H, Kim JR. Electrochemically enhanced microbial CO conversion to volatile fatty acids using neutral red as an electron mediator. Chemosphere 2017; 191: 166-173. 


\section{ACCEPTED MANUSCRIPT}

Jiang Y, Liang P, Zhang C, Bian Y, Yang X, Huang X, et al. Enhancing the response of microbial fuel cell based toxicity sensors to $\mathrm{Cu}(\mathrm{II})$ with the applying of flow-through electrodes and controlled anode potentials. Bioresour Technol 2015; 190: 367-72.

Jin X, Angelidaki I, Zhang Y. Microbial Electrochemical Monitoring of Volatile Fatty Acids during Anaerobic Digestion. Environ Sci Technol 2016; 50: 4422-9.

Jin X, Li X, Zhao N, Angelidaki I, Zhang Y. Bio-electrolytic sensor for rapid monitoring of volatile fatty acids in anaerobic digestion process. Water Res 2017; 111: 74-80.

Jonca J, Ryzhikov A, Palussiere S, Esvan J, Fajerwerg K, Menini P, et al. Organometallic Synthesis of CuO Nanoparticles: Application in Low-Temperature CO Detection. Chemphyschem 2017; 18: 2658-2665.

Kundu S, Sudharson R, Narjinary M. Pd impregnated gallia: tin oxide nanocomposite An excellent high temperature carbon monoxide sensor. Sensors and Actuators B-Chemical 2018; 254: 437-447.

Mehta P, Hussain A, Tartakovsky B, Neburchilov V, Raghavan V, Wang H, et al. Electricity generation from carbon monoxide in a single chamber microbial fuel cell. Enzyme and Microbial Technology 2010; 46: 450-455.

Paliwal A, Sharma A, Tomar M, Gupta V. Carbon monoxide (CO) optical gas sensor based on ZnO thin films. Sensors and Actuators B-Chemical 2017; 250: 679-685.

Shen Y, Wang M, Chang IS, Ng HY. Effect of shear rate on the response of microbial fuel cell toxicity sensor to $\mathrm{Cu}(\mathrm{II})$. Bioresour Technol 2013; 136: 707-10.

Shimizu Y, Yamamoto S, Takase S. A thick-film impedancemetric carbon monoxide sensor using layered perovskite-type cuprate. Sensors and Actuators B-Chemical 2017; 249: 667-672. 


\section{ACCEPTED MANUSCRIPT}

Shojaee M, Nasresfahani S, Sheikhi MH. Hydrothermally synthesized Pd-loaded SnO2/partially reduced graphene oxide nanocompo site for effective detection of carbon monoxide at room temperature. Sensors and Actuators B-Chemical 2018; 254: 457-467.

Sun JZ, Kingori GP, Si RW, Zhai DD, Liao ZH, Sun DZ, et al. Microbial fuel cell-based biosensors for environmental monitoring: a review. Water Science and Technology 2015; 71: 801-809.

Zhang Y, Angelidaki I. Submersible microbial fuel cell sensor for monitoring microbial activity and BOD in groundwater: focusing on impact of anodic biofilm on sensor applicability. Biotechnol Bioeng 2011; 108: 2339-47.

Zhang YF, Angelidaki I. Submersible microbial desalination cell for simultaneous ammonia recovery and electricity production from anaerobic reactors containing high levels of ammonia. Bioresour Technol 2015; 177: 233-239.

Zhou Q, Xu LN, Umar A, Chen WG, Kumar R. Pt nanoparticles decorated SnO2 nanoneedles for efficient CO gas sensing applications. Sensors and Actuators B-Chemical 2018; 256: 656664.

Zhou SF, Huang SB, He JX, Li H, Zhang YQ. Electron transfer of Pseudomonas aeruginosa CP1 in electrochemical reduction of nitric oxide. Bioresour Technol 2016; 218: 1271-1274. 
Table 1 Comparisons of various forms of CO sensors developed recently

\begin{tabular}{|c|c|c|c|c|c|}
\hline Type & Sensing element & $\begin{array}{l}\text { Temperatur } \\
\text { e }\left({ }^{\circ} \mathrm{C}\right)\end{array}$ & $\begin{array}{l}\text { Detection } \\
\text { range }\end{array}$ & $\begin{array}{l}\text { Correla } \\
\text { tion }\end{array}$ & Reference \\
\hline $\begin{array}{c}\text { Chemical translation } \\
\text { sensor }\end{array}$ & Human olfactory system & N/A & $\begin{array}{l}500 \mathrm{ppm}^{-} \\
1600 \mathrm{ppm}^{\text {a }}\end{array}$ & N/A & $\begin{array}{l}\text { (Bergmann et } \\
\text { al., 2017) }\end{array}$ \\
\hline $\begin{array}{l}\text { Organometallic } \\
\text { chemistry sensor }\end{array}$ & $\mathrm{CuO}$ Nanoparticles & 210 & $100 \mathrm{ppm}^{\mathrm{a}}$ & N/A & $\begin{array}{l}\text { (Jonca et al., } \\
\text { 2017) }\end{array}$ \\
\hline Optical gas sensor & $\mathrm{Au} / \mathrm{ZnO}$ sensing film & $\begin{array}{l}\text { Room } \\
\text { temperature }\end{array}$ & $0.5-100 \mathrm{ppm}$ & Linear & $\begin{array}{c}\text { (Paliwal et al., } \\
\text { 2017) }\end{array}$ \\
\hline Impedancemetric sensor & $\begin{array}{c}\text { layered perovskite-type } \\
\text { oxides }\end{array}$ & 400 & $50-600 \mathrm{ppm}$ & Linear & $\begin{array}{c}\text { (Shimizu et al., } \\
\text { 2017) }\end{array}$ \\
\hline $\begin{array}{l}\text { Time division } \\
\text { multiplexing technique }\end{array}$ & $\begin{array}{l}\text { Single-reflection spherical } \\
\text { optical mirror }\end{array}$ & N/A & $\begin{array}{l}2.96-2500 \\
\quad \text { ppm }\end{array}$ & $\begin{array}{c}\text { Expone } \\
\text { ntial }\end{array}$ & $\begin{array}{l}\text { (Dong et al., } \\
\text { 2017) }\end{array}$ \\
\hline Bioelectrical CO Sensor & Bioanode & 25 & $\begin{array}{l}(1-7) \times 10^{5} \\
\text { ppm }\end{array}$ & Linear & This study \\
\hline
\end{tabular}

a. The minimum detection test is not provided by authors 


\section{ACCEPTED MANUSCRIPT}

Figure 1 Schematic illustration of Bioelectrical CO Sensor

Figure 2 The relationship between voltage drop $(\Delta \mathrm{mV})$ and $\mathrm{CO}$ concentrations after $1 \mathrm{~h}$ operation and linear correlation in the CO concentration ranges of $10 \%$ to $70 \%$ (Blue line) and $0 \%$ to $100 \%$ (Orange line), respectively

Figure 3 Voltage of different CO concentrations against time (presented as mean values of multiple tests) (a) and $\mathrm{R}^{2}$ against response time (b)

Figure 4 Typical electricity generation from acetate (red line, without $\mathrm{CO}$ ) and pure $\mathrm{CO}$ (blue line, no acetate). The arrow indicates the time of $100 \% \mathrm{CO}$ input $(4 \mathrm{~mL} / \mathrm{min})$. Before $\mathrm{CO}$ introduction, the MFC was starved for $18 \mathrm{~h}$ to make sure the depletion of organic matters 


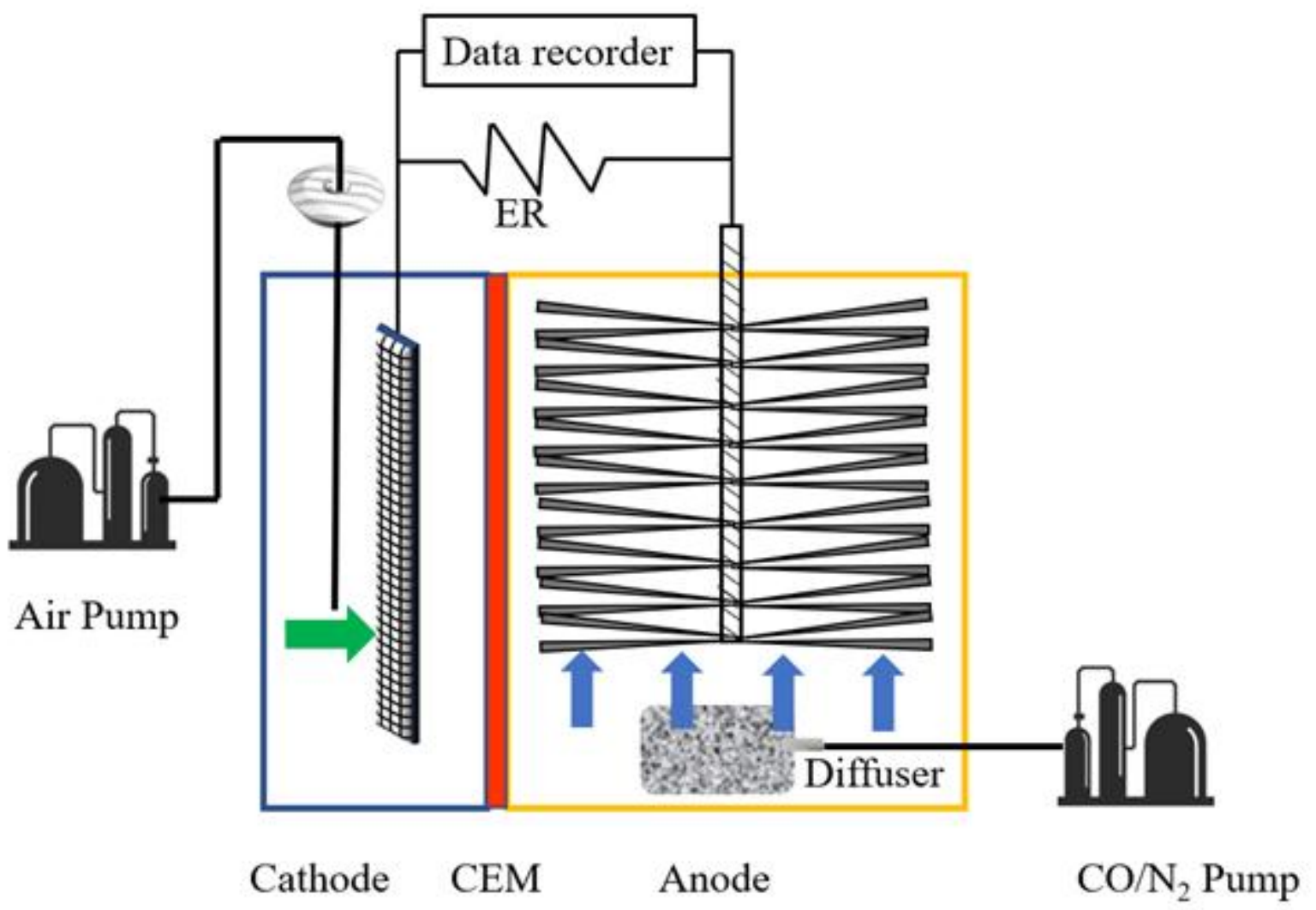

Figure 1 


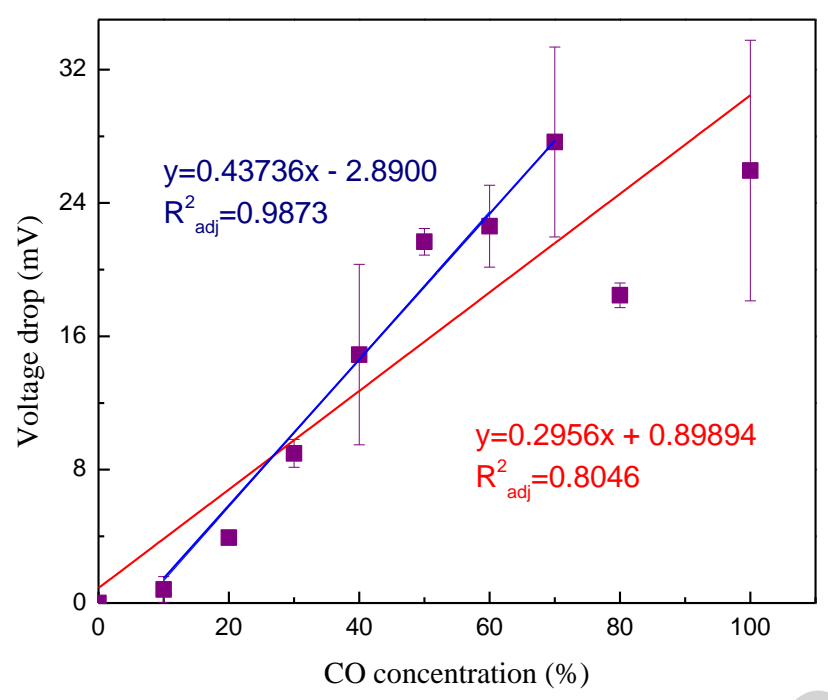

Figure 2 

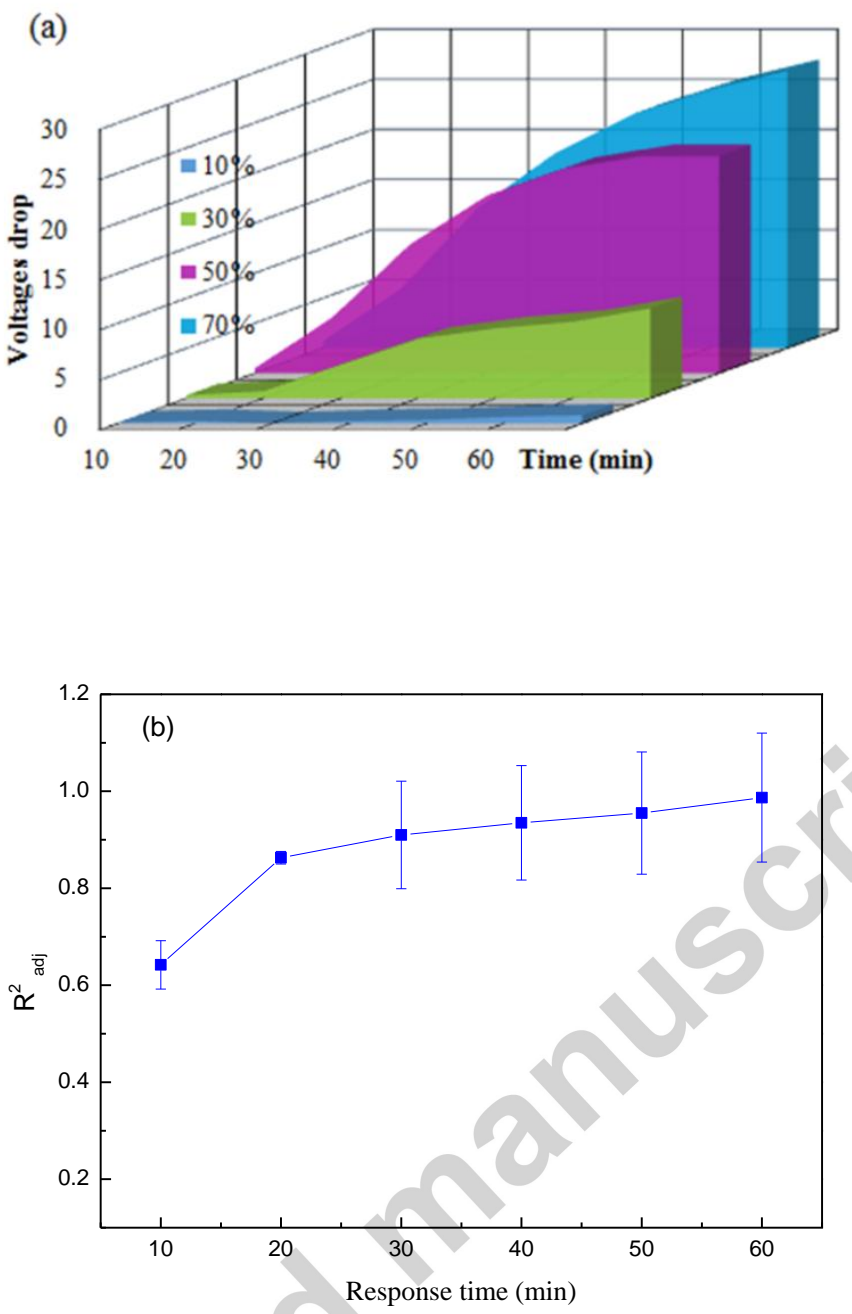

Figure 3 


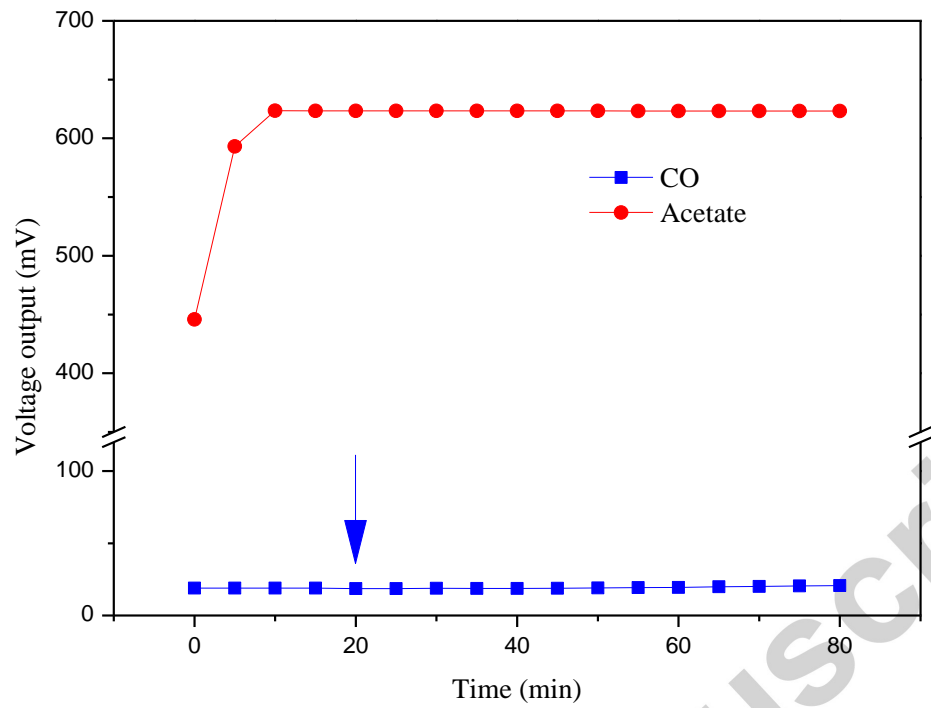

Figure 4 


\section{Highlights}

- A microbial fuel cell-based biosensor for carbon monoxide monitoring.

- Linear relationship between CO concentration (10\% 70\%) and voltage drop.

- The response time for accurate CO monitoring was 1 hour.

- CO inhibits bacterial activity and thereby reduces electricity production.

- The biosensor with compact design and simple operation for on-line monitoring. 